\title{
Comparison of Four Extraction Methods to Detect Hepatitis A Virus RNA in Serum and Stool Samples
}

\author{
Vanessa Salete de Paula, Livia Melo Villar \\ and Ana Maria Coimbra Gaspar
}

\author{
Department of Virology, Oswaldo Cruz \\ Institute, Rio de Janeiro/RJ, Brazil
}

\begin{abstract}
The efficiency of extraction methods for hepatitis A virus (HAV) RNA in clinical samples is of great importance for molecular diagnosis, especially in regions endemic for $\mathrm{HAV}$, such as Brazil. We compared the efficiency of four different extraction techniques in serum and stool samples for the detection of hepatitis A virus by reverse transcription PCR (RT-PCR). We used PCR to analyse serum and stool samples of 12 patients who were referred to the Brazilian Reference Center for Viral Hepatitis (BRCVH) in Rio de Janeiro. The methods tested were Proteinase K, Silica, TRIzol and Guanidine isothiocyanate. Proteinase $\mathrm{K}$ extraction was the best method for serum samples; it detected the HAV-RNA in 11 of the 12 samples. The guanidine isothiocyanate method was the most effective for stool samples, detecting HAV-RNAs in 9 of the samples. The TRIzol ${ }^{\circledR}$ method worked best with serum samples, and the silica method was unsatisfactory with both serum and stool samples. The RNA extraction method affected the outcome. The use of appropriate RNA extraction methods is a critical step for successful and valid PCR studies on clinical samples. We recommend that RNA extraction techniques be carefully selected for their efficiency with each type of specimen.

Key Words: HAV, Extraction methods, serum and stool, RT-PCR.
\end{abstract}

The detection of nucleic acid sequences of microbial organisms is a widely used identification technique in diagnostic and research laboratories. The target nucleic acid sequences are amplified by polymerase chain reaction (PCR) and the products (amplicons) detected in ethidium bromide-stained gels, or by colorimetric enzyme immunoassay. In order to amplify nucleic acids (DNA or RNA), these molecules need to be extracted and separated from other components of microorganisms or cellular materials that could inhibit amplification reactions [1-2]. Traditionally, guanidine isothiocyanate, followed by ethanol precipitation, has been used to obtain RNA from cells and microorganisms Received on 30 July 2002; revised 09 October 2002. Address for correspondence: Dr. Vanessa de Paula, Department of Virology, Oswaldo Cruz Institute, FIOCRUZ, Avenida Brasil 4365, 21045-900. Rio de Janeiro, RJ, Brazil. Phone: + 5521598 4276. Fax.+552127063 97. E-mail vdepaula@ioc.fiocruz.br Grant sponsor: $\mathrm{CNPq}$

The Brazilian Journal of Infectious Diseases 2003;7(2):135-141 (C) 2003 by The Brazilian Journal of Infectious Diseases and Contexto Publishing. All rights reserved.
[3]. In addition to separating and purifying the RNA, this method minimizes inhibition of nucleic acid amplification by PCR in clinical samples $[1,4,5]$.

Hepatitis A virus (HAV) is a picornavirus with a 7.5 $\mathrm{Kb}$ positive strand RNA genome. HAV infection is acquired primarily by the fecal-oral route, by person to person contact or through the ingestion of contaminated food or water [6-7]. Molecular methods provide tools for studying HAV infection; the amplification of HAV RNA by reverse transcription, followed by PCR of the cDNA, is the most sensitive technique for screening clinical specimens. Studies using reverse transcription PCR (RT-PCR) have demonstrated that HAV RNA appears in the blood earlier than what was known from transmission studies; the viremia may be present for a much longer period during the convalescent phase of hepatitis A than was previously thought [8-9]. The efficiency of extraction methods for HAV-RNA in clinical samples is very important for molecular diagnosis, especially in areas endemic for HAV, such as Brazil. 
Gene amplification methods are increasingly being used for virological diagnostic tests due to their specificity and sensitivity [10]. It is more difficult to use RT-PCR to detect viral genomes in serum samples than in stools because of the low concentration of the virus in blood. On the other hand, there are a lot of substances in stools that can interfere with the enzyme system used for amplification, such as bile salts, hemoglobin degradation products and complex polysaccharides [11-13]. We compared the efficiency of four different extraction techniques in serum and stool samples to provide material for the detection of hepatitis A virus by RT-PCR.

\section{Materials and Methods}

Specimens. One hundred samples from individuals who were referred to the Brazilian Reference Center for Viral Hepatitis (BRCVH) in the city of Rio de Janeiro were analyzed with an enzyme immunoassay. Formal consent was obtained from each individual. Serum samples were collected by venipuncture, without anticoagulant, centrifuged at $800 \mathrm{xg}$ for $5 \mathrm{~min}$ at $4{ }^{\circ} \mathrm{C}$ after the blood had clotted, and sent to the laboratory on ice, where they were stored at $-20^{\circ} \mathrm{C}$.

All the serum samples that gave positive ELISA test results were further analyzed using RT-PCR.All antiHAV IgM positive individuals returned one week after the blood collection to provide the stool samples. None of these stool samples appeared to be contaminated by blood.

Serological Tests. IgM and total anti-HAV antibodies were detected by enzyme immunoassay (Organon Teknika, Boxtel, The Netherlands) of serum samples. Serum samples were also tested for hepatitis B surface antigen (HBsAg) and for IgM antibodies directed against the hepatitis B virus core protein (IgM anti$\mathrm{HBc}$ ), using Hepanostika HBsAg Uni-form II and HBc IgM kits (Organon Teknika, Boxtel, The Netherlands), respectively, in order to check for other hepatitis etiologies. Anti-HCV antibodies were detected with an enzyme immunoassay (UBI HCV EIA 4.0 kit, Organon).
RNA Extraction. The protocols were those in current use for the detection of enteroviruses. The same volume $(100 \mu \mathrm{l})$ was used for all extraction methods. Blood and fecal specimens from healthy humans were included as a negative control for every test.

Fecal Preparation. Fecal suspensions [10\% suspension in phosphate-buffered saline solution (PBS) (pH 7.4)] were treated with chloroform, and aliquots were stored at $-70^{\circ} \mathrm{C}$ until extraction.

Proteinase K Method. One hundred microliters of serum or fecal suspension were treated with an equal volume of proteinase $\mathrm{K}(2 \mu \mathrm{g} / \mathrm{ml}$ in $20 \mathrm{mM}$ Tris, $\mathrm{pH}$ $7.5,10 \mathrm{mMEDTA}, 0.1 \% \mathrm{SDS}$ ) at $45^{\circ} \mathrm{C}$ for $1 \mathrm{~h}$. RNA was extracted with phenol-chloroform, precipitated with ethanol, and resuspended in $20 \mu \mathrm{l}$ of DEPC-treated water prior to reverse transcription. After centrifugation, the pellet was washed with $70 \%$ ethanol, air dried, and finally resuspended in $10 \mu \mathrm{l}$ of DEPC treated water.

TRIzol ${ }^{\circledR}$ Method. The TRIzol $\circledast$ extraction was based on the method of Chomczynski and Sacchi [3]; a commercially available mixture of guanidinium isothiocyanate acid and phenol chloroform (Life Technologies, Rockville, MD) was used. One hundred microliters of serum or suspension of feces were mixed with $800 \mu \mathrm{l}$ of TRIzol ${ }^{\circledR}$ LS reagent, $1 \mu \mathrm{l}(10 \mu \mathrm{g})$ of yeast tRNA, and $200 \mu \mathrm{l}$ of chloroform. The mixture was vortexed for $2 \mathrm{~min}$, incubated for $20 \mathrm{~min}$ at room temperature, and centrifuged at $8,000 \mathrm{~g}$ for $20 \mathrm{~min}$ at $4^{\circ} \mathrm{C}$. The upper phase was precipitated with $600 \mu \mathrm{l}$ isopropanol at $-20^{\circ} \mathrm{C}$ for $18-24$ hours. After centrifugation, the pellet was washed with $70 \%$ ethanol, air dried, and finally resuspended in $10 \mu \mathrm{l}$ DEPCtreated water.

Guanidine Isothiocyanate Method. A modified version of the guanidine isothiocyanate (GIT) method was used; $100 \mu$ l of the sample (serum or stool suspension) was mixed with $1 \mu$ l of extraction solution (5.5M guanidine isothiocyanate, $25 \mathrm{mM}$ sodium citrate and sodium lauryl-sarcosine ) and $1 \mu \mathrm{l}(10 \mathrm{mg})$ of yeast tRNA, vortexed for 2 minutes and incubated for 30 minutes, 
at room temperature. This mixture was then centrifuged at $8,000 \mathrm{~g}$ at $4^{\circ} \mathrm{C}$, for 5 minutes. The supernatant was transferred to another tube with $600 \mu$ l of isopropanol and incubated at $-20^{\circ} \mathrm{C}$ for $18-24$ hours.

Silica Method. A protocol described by Boom et al. [14] was used to extract hepatitis A virus RNA from serum and stool samples. One hundred microlitres of each sample (serum or stool suspension) was added to a mixture of $30 \mu \mathrm{l}$ of size-fractionated silica particles and $200 \mu \mathrm{l}$ of lysis buffer L6 (8M guanidine isothiocyanate, $0.1 \mathrm{M}$ tris- $\mathrm{HCl}(\mathrm{pH} 6.4), 36 \mathrm{mM}$ EDTA) and left at room temperature for 10 minutes, after which it was centrifuged at $8,000 \mathrm{~g}$ for 30 seconds to sediment the nucleic acid-silica particle complexes. The pellet was washed once with $200 \mu$ l of washing buffer L2 [10 M guanidine isothiocyanate, 0.1 M Tris$\mathrm{HCl}$ (pH 6.4)], twice with $500 \mu \mathrm{l}$ of $70 \%$ (v/v) ethanol and once with $500 \mu \mathrm{l}$ of acetone. The pellet was dried at $56^{\circ} \mathrm{C}$ for 10 minutes and the nucleic acids eluted with $1 \mu \mathrm{l}$ of RNAsin (Life Technologies) in $60 \mu \mathrm{l}$ of water, at $56^{\circ} \mathrm{C}$ for 10 minutes. The tube was centrifuged at $8,000 \mathrm{~g}$ for 2 min to sediment the silica particles, and the supernatant containing the RNA was used for cDNA synthesis and enzymatic DNA amplification.

Amplification by RT-PCR. All reverse transcription was carried out using $10 \mu \mathrm{l}$ RNA, 20 pmol of Random primer (Life Technologies) and $200 \mathrm{U}$ of Super-Script II reverse transcriptase (Life Techologies) in a final volume of $20 \mu \mathrm{l}$ at $42^{\circ} \mathrm{C}$ for $1 \mathrm{~h}$, followed by incubation for $10 \mathrm{~min}$ at $65^{\circ} \mathrm{C}$.

Ten microlitres of the cDNA was used for PCR. After denaturation for $4 \mathrm{~min}$ at $94^{\circ} \mathrm{C}$, the DNA was amplified for 30 cycles at $94^{\circ} \mathrm{C}$ for $30 \mathrm{~s}, 40^{\circ} \mathrm{C}$ for 30 $\mathrm{s}$, and $72^{\circ} \mathrm{C}$ for $1 \mathrm{~min}$ (and an additional $7 \mathrm{~min}$ at $72^{\circ} \mathrm{C}$ in the last cycle), in a final volume of $50 \mu \mathrm{l}$. The primers used in this first round of PCR were based on previously described primers sense +2897 and antisense -3288 [9], degenerated as follows to be able to amplify all HAV genotypes ('universal primers'): 5' CTATTCAGATTGCAAATTAYAAT 3' (sense) and 5' AAYTTCATY ATTTCATGCTCCT 3' (antisense), where $Y$ represents $C$ or $T$. Nested PCR was carried out with $1 \mu \mathrm{l}$ of the first round PCR product for 30 cycles under the same conditions (only increasing annealing temperature to $48^{\circ} \mathrm{C}$ ). Internal primers were +2949 and -3192 [15], modified as follows: 5' T ATTTGTCTGTYACAGAACAATCAG 3’ (sense) and 5' AGGRGGTGGAAGYAC TTCATTTGA 3' (antisense), where $\mathrm{R}$ represents A or G. PCR products $(10 \mathrm{ml})$ were loaded on a $1.5 \%$ agarose electrophoresis gel prepared on TAE, and stained with $1 \mu \mathrm{g} / \mathrm{ml}$ of ethidium bromide to visualize a band with an expected length of 244 base pairs, using UVP $\AA$ Vision Works software (UVP®, Cambridge, UK).

\section{Results}

Detection of Anti-HAV Antibodies. Among 100 blood samples collected from patients (sporadic cases) who were referred to the BRCVH, Rio de Janeiro, Brazil, 30 were positive for IgM anti-HAV antibodies. None of them was positive for IgM anti-HBc, HBsAg, IgM anti-HBc or anti-HCV. Among the 30 anti-HAV IgM positive subjects, only 12 returned a week later to give a fecal sample. All the individuals were 3 to 16 years old, and most of them were female (7/12) and symptomatic (10/12). The main characteristics of this population are summarized in Table 1.

Detection of HAV RNA in Serum and Stool Samples. The HAV RNA was tested by RT-PCR in the 12 serum and 12 stool samples. Four different extraction techniques were then used on these samples prior to RT-PCR, and the amplified products were detected by electrophoresis on agarose gel, generating a 244 bp DNA fragment (Figure 1). The experiments for each protocol were repeated three times. The serum and stool samples from all the patients were tested for HAV RNA with four extraction methods (Table 2).

The GIT method was the most efficient at lysing viral particles in the stool samples, giving positive scores in 9/12. The second most sensitive method for stool samples was the proteinase $\mathrm{K}$ method, which found HAV RNA in 8/12. This method was the most sensitive in serum samples; HAV RNA was detected in 11/12. The TRIzol ${ }^{\circledR}$ protocol gave $7 / 12$ positives in stool 
Table 1. General characteristics of the patients who were analyzed for hepatitis A virus

\begin{tabular}{ccccc}
\hline Patient no. & Age & Sex & TGO/TGP & Clinical symptoms \\
\hline 1 & 8 & F & ND & Asymptomatic \\
2 & 4 & M & $214 / 315$ & Symptomatic \\
3 & 4 & F & $27 / 21$ & Symptomatic \\
4 & 3 & F & $685 / 301$ & Symptomatic \\
5 & 11 & F & ND & Asymptomatic \\
6 & 13 & M & $2078 / 1825$ & Symptomatic \\
7 & 16 & F & $53 / 120$ & Symptomatic \\
8 & 03 & F & $53 / 200$ & Symptomatic \\
9 & 14 & M & $46 / 18$ & Symptomatic \\
10 & 16 & M & $17 / 23$ & Symptomatic \\
11 & 05 & F & $42 / 32$ & Symptomatic \\
12 & 10 & M & $37 / 23$ & Symptomatic \\
\hline
\end{tabular}

TGO: Glutamic Oxaloacetic Transaminase, TGP: Glutamic Pyruvic Transaminase, ND: no data.

Table 2. Comparison of four extraction methods for hepatitis A virus RNA detection in stools and serum samples

Presence of HAV RNA in samples subjected to

Presence of antiextraction methods indicated

HAV antibodies

\begin{tabular}{|c|c|c|c|c|c|c|c|c|c|c|}
\hline \multirow{2}{*}{$\begin{array}{c}\text { Patient } \\
\text { (n) }\end{array}$} & \multicolumn{4}{|c|}{ Stool } & \multicolumn{4}{|c|}{ Serum } & \multirow[b]{2}{*}{$\operatorname{IgM}$} & \multirow[b]{2}{*}{ Total } \\
\hline & GIT & PK & SI & TR & GIT & PK & SI & TR & & \\
\hline 1 & + & + & + & + & - & + & - & - & + & + \\
\hline 2 & + & + & + & + & + & + & + & + & + & + \\
\hline 3 & + & - & + & - & - & - & - & + & + & + \\
\hline 4 & + & - & + & + & - & + & + & + & + & + \\
\hline 5 & + & - & - & - & - & + & - & - & + & + \\
\hline 6 & + & + & + & + & + & + & + & + & + & + \\
\hline 7 & + & + & - & + & + & + & + & + & + & + \\
\hline 8 & - & + & - & - & + & + & + & + & + & + \\
\hline 9 & + & + & - & + & - & + & + & + & + & + \\
\hline 10 & + & + & - & + & + & + & - & - & + & + \\
\hline 11 & - & - & - & - & + & + & - & + & + & + \\
\hline 12 & - & + & + & - & - & + & - & - & + & + \\
\hline Total & $9 / 12$ & $8 / 12$ & $6 / 12$ & $7 / 12$ & $6 / 12$ & $11 / 12$ & $6 / 12$ & $8 / 12$ & $12 / 12$ & $12 / 12$ \\
\hline
\end{tabular}

GIT $=$ Guanidine isothiocyanate, $\mathrm{PK}=$ Proteinase $\mathrm{K}, \mathrm{SI}=$ Silica, $\mathrm{TR}=\mathrm{TRIzol}$. 
Figure 1. A 1.5\% agarose gel electrophoresis demonstrating the corrected size amplicons generated by a RTPCR for HAV after TRIzol ${ }^{\circledR}$ extraction. Lane A, $\phi x$ molecular weight; lanes 1, distilled $\mathrm{H}_{2} \mathrm{O}$ as a negative control; lanes 3, 5: negative serum samples; lane 7 and 9: negative fecal samples; lanes 2 and 4, positive serum samples; lane 6, positive fecal sample; lane 8, HAF-203, Brazilian strain as a positive control.

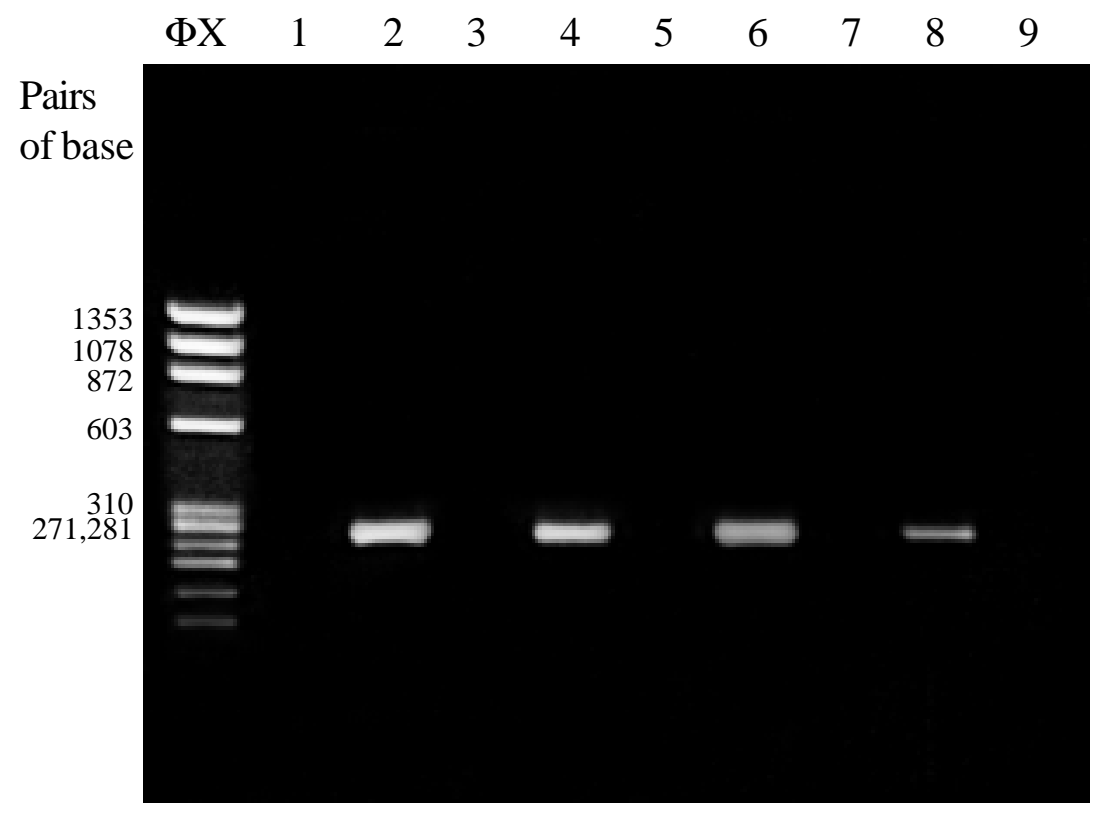

samples and 8/12 in serum samples. The silica method gave the worst results for both serum and stool samples; only half of the specimens tested positive (6/12).

\section{Discussion}

Hepatitis A has long been a major public health problem in many countries, especially in areas where infection patterns are changing from hyperendemic to hypoendemic [16-19]. Brazil has traditionally been an area of high endemicity; infection occurs mainly in children up to five years of age [20-22]. However with the general improvements in hygiene and sanitation standards, the level of HAV infection has declined dramatically in recent years, and in some urban regions of Brazil it has shifted from a high to an intermediate endemicity status [23]. This new epidemiological pattern has increased the number of susceptible people and has created a potential for large-scale epidemics [24]. Four methods of RNA extraction commonly used in virology laboratories were evaluated in an effort to improve HAV diagnosis by PCR; these were the guanidine isothiocyanate method, the proteinase $\mathrm{K}$ method, the TRIzol ${ }^{\circledR}$ method and the silica method. Sera and feces from patients who were referred to the BRCVH were processed with all four methods to determine which was the best technique for viral RNA extraction, while all other steps of RT-PCR were kept constant.

We found that the different extraction techniques resulted in variable sensitivities of PCR detection of HAV RNA in human fecal samples. With the GIT method we are able to detect HAV RNA in 9/12 of the stool samples collected during the acute phase of disease; it proved to be very effective for eliminating inhibitors from stool samples. The proteinase K method was also able to eliminate inhibitory factors, however it gave some false negative results, when compared to the GIT method. Probably this occurred because guanidine isothiocyanate disrupts cellular integrity and inhibits nucleases. Apparently there were various types of amplification inhibitors in the fecal specimens and the different extraction methods removed different inhibitory substances. Possible inhibitors include bile salts, hemoglobin degradation products, and complex plant polysaccharides [12-13]. Furthermore, a one- 
week delay in stool sample collection could have reduced virus levels.

Compared to blood or other clinical samples, the complex microbial flora, variable consistency and variable endogenous and dietary components of feces make RNA extraction particularly difficult. The purity of RNA extracted from this heterogeneous material is critical for the sensitivity and usefulness of further analyses, such as PCR analysis for infectious pathogens.

When we evaluated the four extraction methods, the proteinase K method detected HAV RNA in 11 of 12 serum samples. Probably this technique was the most efficient, because the use of the proteinase $\mathrm{K}$ solution followed by phenol-chloroform extraction reduces the concentration of residual protein and membrane components that could inhibit Taq polymerase activity. RNA extraction with phenolchloroform is the most labor-intensive method and it requires additional safety measures for the handling and disposing of phenol. In other studies phenol-chloroform method was reported to be more effective in extracting viral RNA from serum than other techniques [25-26]. The results obtained with TRIzol ${ }^{\circledR}$ confirmed that this technique can be used with serum samples, as previously demonstrated by other researchers [27]. This technique is one of the most suitable for routine diagnosis, in view of its rapidity. However, the presence of lipids in serum samples can interfere in extraction and also in amplification, leading to false negative results.

The silica RNA extraction method was the least efficient for the extraction of hepatitis A virus. This method is frequently used for the virological testing of serum and stool specimens [28-29]. However, it requires complicated buffers, various ultracentrifugations and careful pipetting to remove the RNA solution from the silica beads. The additional pipetting or handling required can increase the risk of losing the RNA. Only $50 \%$ of the specimens were positive with this method.

The choice of an extraction technique that can be used for routine testing of a large number of samples must take into account simplicity of use, rapidity of execution, yield, cost and enhancement of sensibility of HAV molecular diagnosis. The average time required to process the series of 12 specimens varied from 120 150 minutes with each of the four techniques that we tested.

None of these techniques were efficient for both serum and stool samples. The proteinase K digestion, with phenol-chloroform extraction prior to RT-PCR, was the most effective for HAV RNA extraction; and the guanidine isothiocyanate method was the most efficient for stool samples. We conclude that the choice of appropriate RNA extraction methods is a critical step for the successful and valid use of PCR exams on clinical samples. Consequently, we recommend that RNA extraction techniques be carefully selected, with particular regard to the type of specimen.

\section{Acknowledgements}

We thank Messias Silva for technical support.

\section{References}

1. Wiedbrauk D.L., Werner J.C., Drevon A.M. Inhibition of PCR by aqueous and vitreous fluids. J Clin Microbiol 1995;33:2643-6.

2. Schepetiuk S., Kok T., Martin L., et al. Detection of Chlamydia trachomatis in urine samples by nucleic acid tests: comparison with culture and enzyme immunoassay of genital swab specimens. J Clin Microbiol 1997;35:3355-7.

3. Chomczynski P., Sacchi N. Single-step method of RNA isolation by acid guanidinium thiocyanate-phenolchloroform extraction. Anal Biochemistry 1987;162:156-9.

4. Khan G., Kangro H.O., Coates P.J., Heath R.B. Inhibitory effects of urine on the polymerase chain reaction for cytomegalovirus DNA. J Clin Pathol 1991;44:360-5.

5. Ruano G., Pagliaro E.M., Schwartz T.R., et al. Heat soaked PCR: an efficient method for DNA amplification with applications to forensic analysis. Biotechniques 1992;13:266-74.

6. McCaustland K.A., Bond W.W., Bradley D.W., et al. Survival of hepatitis A virus in feces after drying and storage for one month. J Clin Microbiol 1982;16:957-8.

7. Sobsey M.D., Shields P.A., Hauchman F.S., et al. Survival and persistence of hepatitis A virus in environmental samples In: Zuckerman AJ (Editor). Viral Hepatitis and Liver Disease. Liss, New York, 1988.

8. Fujiwara K., Yokosuka O., Ehata T., et al. Frequent detection of hepatitis A viral RNA in serum during the early convalescent phase of acute hepatitis A. Hepatology 1997;26:1634-9. 
9. Bower W.A., Nainan O.V., Han X., Margolis H.S. Duration of viremia in hepatitis A virus infection. J Infect Dis 2000;182:12-7.

10. Clementi M., Menzo S., Bagnarelli P., et al. Quantitative PCR and RT-PCR in virology. PCR Methods Applied 1993; $2: 191-6$.

11. Wilde J., Eiden J., Yolken R. Removal of inhibitory substances from human fecal specimens for detection of group A rotaviruses by reverse transcriptase and polymerase chain reactions. J Clin Microbiol 1990;28:1300-7.26.

12. Widjojoatmodjo M.N., Fluit A.C., Torenma R. et al. The magnetic immuno polymerase chain reaction assay for direct detection of salmonellae in fecal samples. J Clin Microbiol 1992;30:3195-9.

13. Monteiro L., Bonnemaison D., Vekris A., et al. Complex polysaccharides as PCR inhibitors in feces: Helycobacter pylori model. J Clin Microbiol 1997;35:995-8.

14. Boom R., Sol C.J., Salimans M.M., et al. Rapid and simple method for purification of nucleic acids. J Clin Microbiol 1990; $28: 495-503$.

15. Robertson B.H., Jansen R.W., Khanna B., et al. Genetic relatedness of hepatitis A virus strains recovered from different geographical regions. J Gen Virol 1992;73:1365-77.

16. Barzaga N.G. Hepatitis A shifting epidemiology in SouthEast Asia and China. Vaccine 2000;18 (Suppl. 1):S61-4.

17. Cianciara J. Hepatitis A shifting epidemiology in Poland and Eastern Europe. Vaccine 2000;18 (Suppl 1): S68-70.

18. Tanaka J. Hepatitis A shifting epidemiology in Latin America. Vaccine 2000; 18(Suppl 1):S57-60.

19. Tufenkeji H. Hepatitis A shifting epidemiology in Middle East and Africa. Vaccine 2000;18(Suppl 1): S65-7.

20. Pannuti C.S., Mendonça J.S., Carvalho M.J.M., et al. Hepatitis A antibodies in two socio-economically distinct populations of São Paulo, Brazil. Rev Inst Med Trop São Paulo 1985;27:162-4.

21. Abuzwaida A.R.N., Sidoni M., Yoshida C.F.T., Schatzmayr H.G. Seroepidemiology of hepatitis A and hepatitis B in two urban communities of Rio de Janeiro, Brazil. Rev Inst Med Trop São Paulo 1987;24:219-23.

22. Bensabath G.., Hadler S.C., Pereira Soares M.C., et al. Caracteristicas serologicas y epidemiologicas de la hepatitis virica aguda en la cuenca amazonica del Brasil. Bol Of Sanit Panamericana 1987;103:351-62.

23. Vitral C.L., Yoshida C.F.T., Lemos E.R.S., et al. Age-specific prevalence of antibodies to hepatitis $\mathrm{A}$ in children and adolescents from Rio de Janeiro, Brazil, 1978 and 1995. Relationship of prevalence to environmental factors. Mem Inst Oswaldo Cruz 1998;93:1-5.

24. Villar L.M., da Costa M.C.E., de Paula V.S., Gaspar A.M.C. Hepatitis A outbreak in a public school in Rio de Janeiro, Brazil. Mem Inst Oswaldo Cruz 2002;97:301-5.
25. Turkoglu S., Lazizi Y., Meng H., et al. Detection of hepatitis E virus RNA in stools and serum by reverse transcription-PCR. J Clin Microbiol 1996;34:1568-71.

26. Fanson B.G., Osmack P., Di Bisceglie A.M. A comparison between the phenol-chloroform method of RNA extraction and the QIAamp viral RNA kit in the extraction of hepatitis $\mathrm{C}$ and $\mathrm{GB}$ virus-C/hepatitis $\mathrm{G}$ viral RNA from serum. J Virol Methods 2000;89:23-7.

27. Arnal C., Ferré-Aubineau V., Besse B., et al. Comparison of seven RNA extraction methods on stool and shellfish samples prior to hepatitis A virus amplification. J Virol Methods 1999;77:17-26.

28. Green J., Norcott J.P., Lewis D., et al. Norwalk-like viruses: demonstration of genomic diversity by polymerase chain reaction. J Clin Microbiol 1993;31:3007-12.

29. Hale A.D., Green J., Brown D.W. Comparison of four RNA extraction methods for the detection of small round structured viruses in faecal specimens. J Virol Methods 1996;57:195-201. 